\title{
Detecting the Conspecific: Herbivory-Induced Olfactory Cues in the Fall Armyworm (Lepidoptera: Noctuidae)
}

\author{
David A. Ingber ${ }^{1, *}$, Shawn A. Christensen ${ }^{2}$, Hans T. Alborn ${ }^{2}$ and Ivan Hiltpold ${ }^{1,3, *(\mathbb{D}}$ \\ 1 Department of Entomology and Wildlife Ecology, University of Delaware, Newark, DE 19716, USA \\ 2 United States Department of Agriculture, Agricultural Research Service, Gainesville, FL 32608, USA; \\ shawn.christensen@usda.gov (S.A.C.); hans.alborn@usda.gov (H.T.A.) \\ 3 Agroscope Changins, Entomology in Field Crops and Viticulture, Plant Protection Strategic Research \\ Division, 1276 Nyon, Switzerland \\ * Correspondence: david.ingber@scranton.edu (D.A.I.); ivan.hiltpold@agroscope.admin.ch (I.H.); \\ Tel.: +1-570-941-5449 (D.A.I.)
}

check for updates

Citation: Ingber, D.A.; Christensen, S.A.; Alborn, H.T.; Hiltpold, I.

Detecting the Conspecific:

Herbivory-Induced Olfactory Cues in the Fall Armyworm (Lepidoptera:

Noctuidae). Metabolites 2021, 11, 583. https: / doi.org/10.3390/metabo11090583

Academic Editors:

Hirokazu Kawagishi and Peter Meikle

Received: 15 June 2021

Accepted: 23 August 2021

Published: 30 August 2021

Publisher's Note: MDPI stays neutral with regard to jurisdictional claims in published maps and institutional affiliations.

\begin{abstract}
The fall armyworm (FAW), Spodoptera frugiperda (Smith), is a polyphagous pest whose larval feeding threatens several economically important crops worldwide with especially severe damage to corn (Zea mays L.). Field-derived resistance to several conventional pesticides and $\mathrm{Bt}$ toxins have threatened the efficacy of current management strategies, necessitating the development of alternative pest management methods and technologies. One possible avenue is the use of volatile organic compounds (VOCs) and other secondary metabolites that are produced and sequestered by plants as a response to larval feeding. The effects of conspecific larval feeding on fall armyworm oviposition preferences and larval fitness were examined using two-choice oviposition experiments, larval feeding trials, targeted metabolomics, and VOC analyses. There was a significant preference for oviposition on corn plants that lacked larval feeding damage, and larvae fed tissue from damaged plants exhibited reduced weights and head capsule widths. All larval feeding promoted significantly increased metabolite and VOC concentrations compared to corn plants without any feeding. Metabolite differences were driven primarily by linoleic acid (which is directly toxic to fall armyworm) and tricarboxylic acids. Several VOCs with significantly increased concentrations in damaged corn plants were known oviposition deterrents that warrant further investigation in an integrated pest management context.
\end{abstract}

Keywords: Spodoptera frugiperda; corn; oviposition; HIPV; VOC; metabolites; FAW; management

\section{Introduction}

The fall armyworm (FAW), Spodoptera frugiperda (Smith), (Lepidoptera: Noctuidae) is a highly polyphagous, multivoltine pest of many pasture, turf, and agricultural crops [1,2]. Its larval host range spans over 80 host plants in 23 families [3] including economically important crops such as corn (Zea mays L.), cotton (Gossypium Spp. L.), sorghum (Sorghum bicolor L.), rice (Oryza sativa L.), and a variety of pasture and turf grasses $[1,4,5]$. Larval feeding damage is especially severe in corn, where yield losses can range from $17 \%$ to as high as $72 \%$ [6-8]. The fall armyworm is native to the Americas, where outbreaks have been recorded since the late 1700s [1,2]. However, populations of the pest have spread throughout the Eastern hemisphere over the past several years including Africa, India, Southeast Asia, China, and Australia [9-16].

Fall armyworm populations in corn systems are currently managed worldwide largely through the use of chemical insecticides, as well as transgenic plant hybrids that produce toxins derived from the bacterium Bacillus thuringiensis Berliner $(\mathrm{Bt})$ in some locales. The continued efficacy of these management tools is threatened due to many instances of fieldderived resistance to several chemicals in the pyrethroid, organophosphate, and carbamate families [17-20]; and Bt resistance beginning in late 2006 [21]. 
There are currently very few avenues for commercial fall armyworm management that do not involve the use of conventional insecticides or Bt crop hybrids. However, herbivorous insects are known to respond to herbivore-induced plant volatiles (HIPVs), thus HIVPs that repel oviposition by female fall armyworms may provide a novel avenue for fall armyworm integrated pest management (IPM) and insect resistance management (IRM). For example, Signoretti et al. [22] reported data from a series of Y-tube experiments that female fall armyworms strongly preferred the volatiles of undamaged corn plants over those of plants with larval feeding. The reported preference may be an adaptive behavior to avoid competition between newly hatched and already established larvae [22] Téllez-Rodriguez et al. [23] later applied this concept in an IRM context by conducting field trials using Bt field-corn and non-Bt refuge plants. It was determined that fall armyworm females exhibited a preference towards oviposition on plants with little insect feeding damage [23]. In this context, the corn plants with less feeding damage were Bt plants, as they generally suffered lower degrees of herbivory due to the activity of their toxins (the presence of Bt does not appear to deter fall armyworm oviposition [24]). This deterrence also extends to mechanical damage [25]. The use of HIPVs to repel female oviposition could be a potential avenue to bolster existing technologies, extending their time of efficacy, or possibly serving as a stand-alone method of pest management.

To better understand why gravid females avoid conspecific damaged plants, we herein measure the effects of non-cannibalistic larval competition in the fall armyworm by examining the effects of conspecific tissue feeding on female oviposition, hatch rates, larval survival, and larval fitness; as well as comparing targeted metabolomic and volatile organic compound (VOC) profiles of corn plants with and without feeding damage. The results herein yield candidate chemicals that may serve as foliar deterrents to fall armyworm feeding and oviposition, bolstering existing technologies or possibly serving as stand-alone management tools.

\section{Results}

\subsection{Two-Choice Oviposition Experiment}

In examining the effects of conspecific damage on possible oviposition targets it was found that female fall armyworms deposited significantly more egg masses on undamaged control plants than on induced plants with larval feeding (Table 1). The hatch rates of the deposited egg masses did not differ significantly between control and induced corn plants (Table 1).

Table 1. Oviposition, hatch, and larval growth data from two-choice oviposition experiments and feeding trials.

\begin{tabular}{cccccc}
\hline Parameter & Control $^{\mathbf{a}}$ & Induced $^{\mathbf{a}}$ & $\mathbf{d f}^{\mathbf{b}}$ & $\boldsymbol{t}$-Value & $\boldsymbol{p}$-Value \\
\hline Egg Masses ${ }^{\mathrm{c}}$ & $0.47 \pm 0.15$ & $0.09 \pm 0.06$ & 92 & 2.17 & 0.0325 \\
Hatch Rate & $0.87 \pm 0.03$ & $0.93 \pm 0.01$ & 24 & -0.98 & 0.3373 \\
Live Weight $^{\mathrm{d}}$ & $8.01 \pm 1.17$ & $4.68 \pm 1.09$ & 25 & 1.61 & 0.1201 \\
Dry Weight $^{\mathrm{d}}$ & $1.01 \pm 0.14$ & $0.67 \pm 0.15$ & 25 & 1.65 & 0.1112 \\
HCW $^{\mathrm{e}, \mathrm{f}}$ & $1.00 \pm 0.06$ & $0.77 \pm 0.05$ & 25 & 3.02 & 0.0057 \\
\hline
\end{tabular}

${ }^{\mathrm{a}}$ Mean \pm Standard Error. ${ }^{\mathrm{b}}$ Degrees of freedom representing each individual egg mass across all replicates. ${ }^{c}$ Generalized Linear Model with Quasi-Poisson distribution. ${ }^{d}$ Measured in mg. ${ }^{e}$ Head Capsule Width. ${ }^{\mathrm{f}}$ Measured in $\mathrm{mm}$.

\subsection{Feeding Trials}

The feeding trials were conducted to examine the effects of conspecific feeding on fall armyworm larval development. There were no significant differences in the live or dry weights of larvae fed either control or induced corn plant tissue (Table 1). Fall armyworm larvae fed induced corn plant tissue had significantly decreased head capsule widths compared to those fed control plant tissue (Table 1). 


\subsection{Targeted Metabolomic Analyses}

Analyses were conducted to identify corn plant metabolites that may drive the results of the feeding trials. The first discriminant axis LD1 of the model accounted for $85 \%$ of between-group variance (Figure 1). The LD analyses showed a significant difference between the no feeding (control) treatment compared to the remaining three treatments (feeding only, prefeeding only, and prefeeding and feeding together). Larval feeding as a whole affected the targeted metabolomics of maize. Pre-feeding did not result in significant changes to metabolic profiles. (Figure 1)

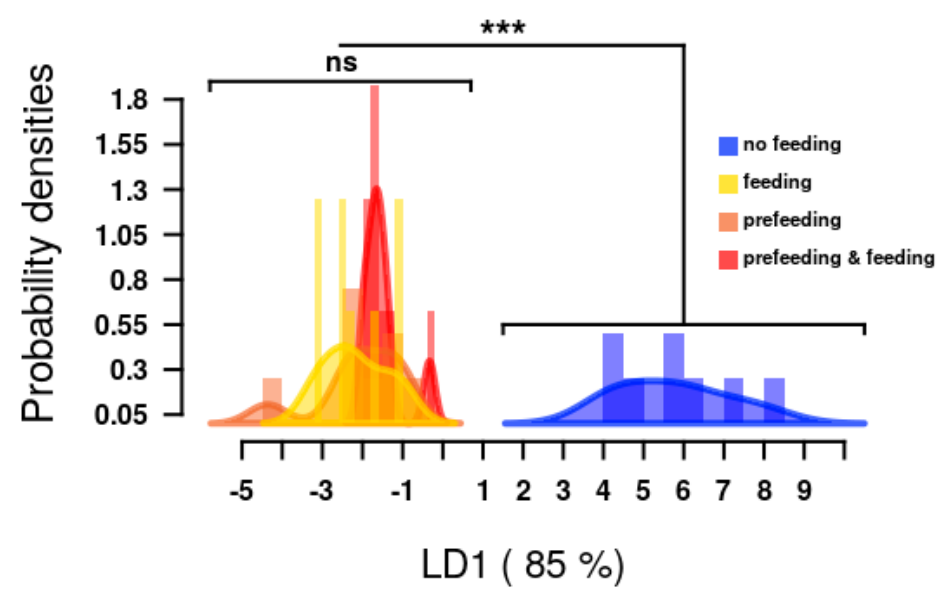

Figure 1. Linear discriminant analysis and change of targeted corn metabolite profiles under four different feeding treatments. Histograms show the distribution of discriminant scores of the metabolomic profiles produced by plants with no feeding (blue), feeding only (yellow), prefeeding only (brown), and prefeeding and feeding together (red). Significant differences between groups of plants are indicated by asterisks, ns: $p>0.05$ (pairwise Wilcoxon test; $p<0.05$ after Benjamini and Hochberg correction). The first LD1 explains $85 \%$ of the between-group variance.

Linoleic acid and tricarboxylic acids (TCAs) were significant discrimination drivers ( $p<0.0001$ and $p=0.049$, respectively) among the targeted metabolites included in the LD1 model, whereas 6-methoxy-benzoxazolin-2-one, indole-3-acetic acid, palmitic acid, oleic acid, steric acid, linolenic acid, eicosanoic acid, docosanoic acid, tetracosanoic acid, cis-12-oxo-phytodienoic acid, cis-10-oxo-11-phytoenoic acid, and cis-10-oxo-phytodienoic acid each resulted in marginal discrimination (Figure 2).

\subsection{VOC Analysis}

The VOC profiles of control and induced plants were examined to identify chemical candidates that may be driving the results of the two-choice oviposition experiments. There were no differences in the compounds present in the VOC profiles of control and induced corn plants, though the induced plants produced significantly greater concentrations of volatile organic compounds on average than control plants $(p<0.001)$. There were also significant differences in the concentrations of $(E)$-2-hexanal, ( $Z$ )-3-hexan-1-ol, ( $Z$ )-3-hexenyl acetate, $(Z)$ - $\beta$-ocimene, linalool, (E)-4,8-dimethyl-1,3,7-nonatriene (DMNT), (E)- $\beta$-farnese, (E)-nerolidol, and (3E,7E)-4,8,12-trimethyl-1,3,7,11-tridecatetraene (TMTT) between the two treatment groups (Figure 3). 


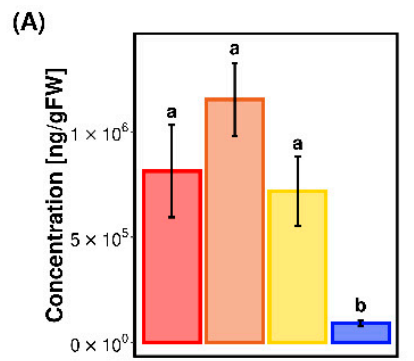

(G)

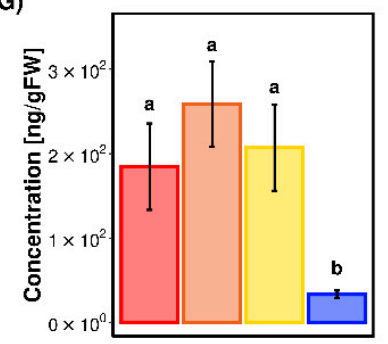

(M)

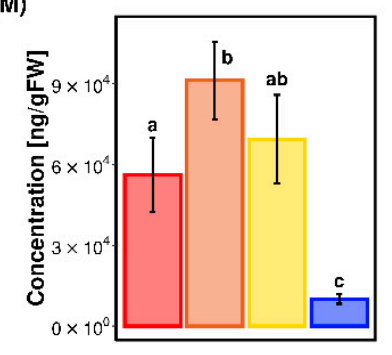

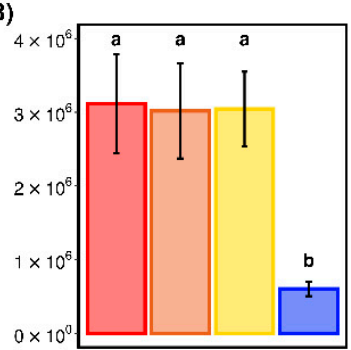

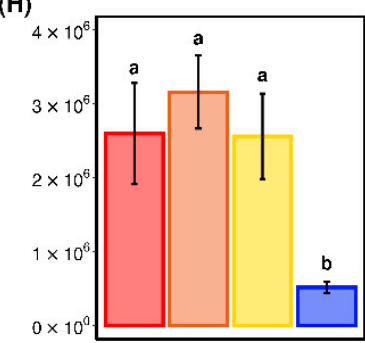

(N)

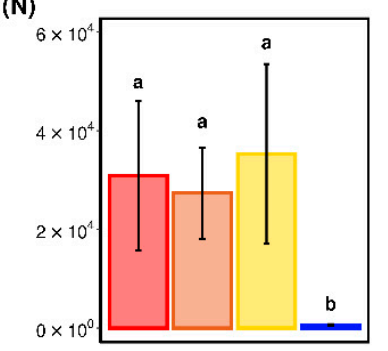

(C)
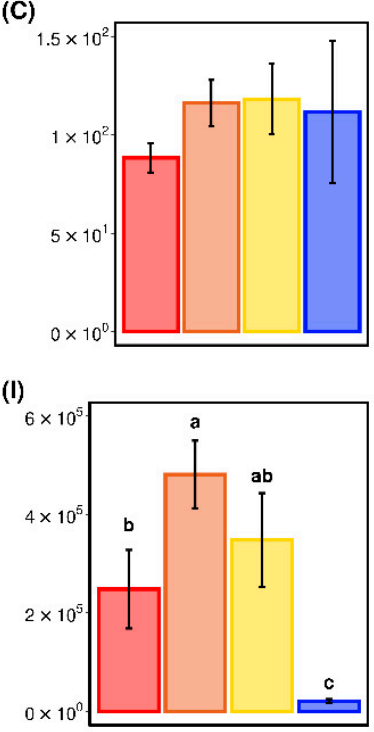

(0)

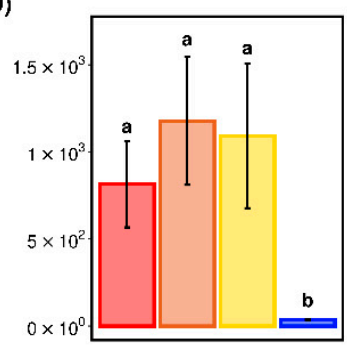

(D)

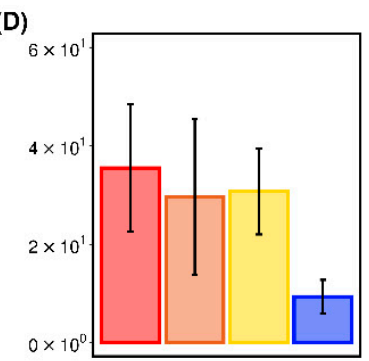

(J)

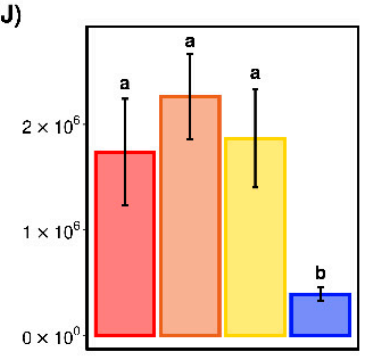

(P)

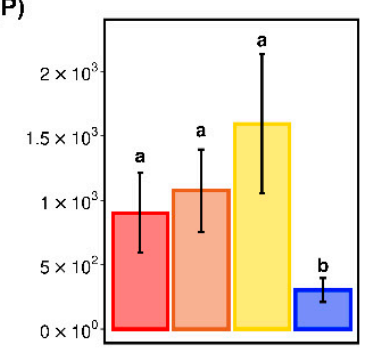

(E)

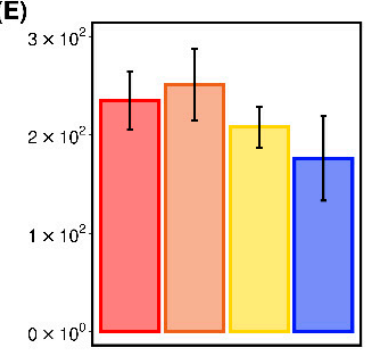

(K)

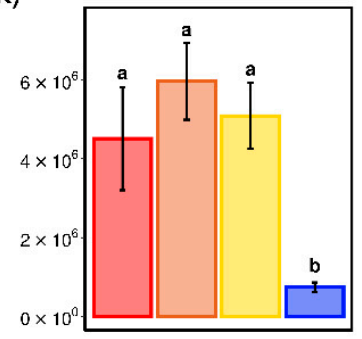

(F)

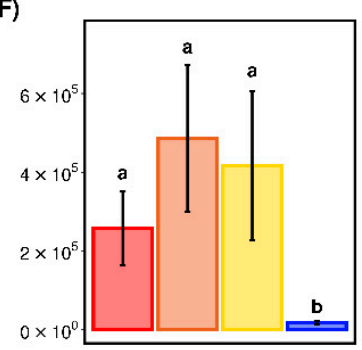

(L)

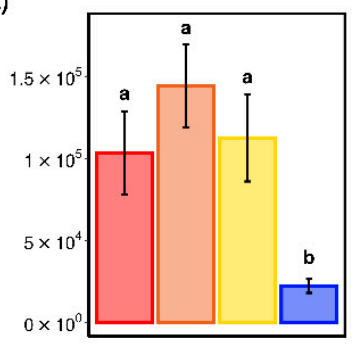

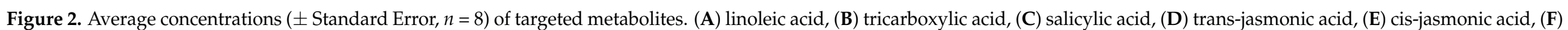

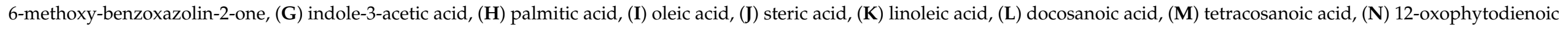

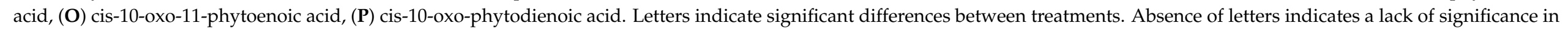
the overall ANOVA model. 


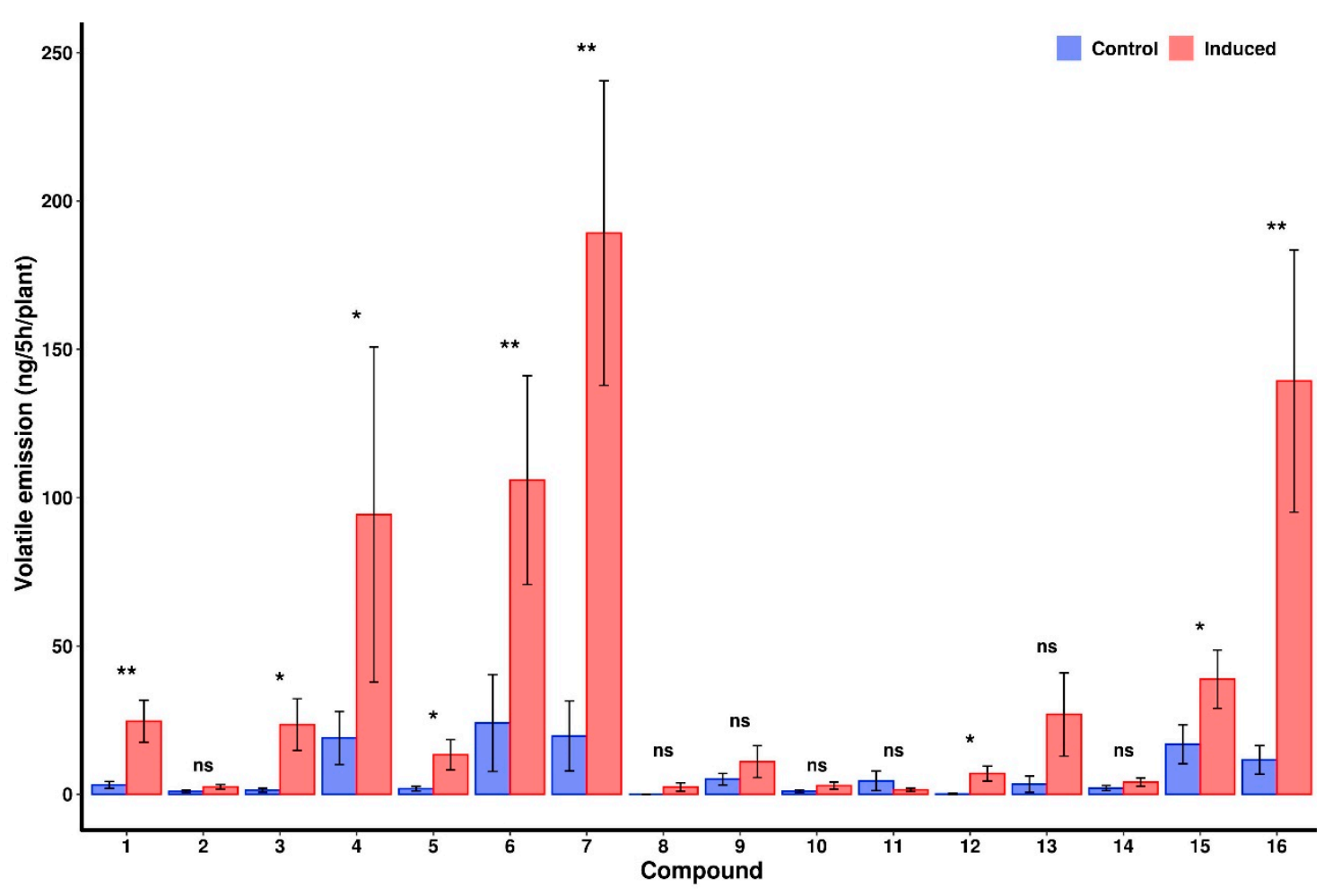

Figure 3. Average nighttime volatile emission rates $(+/-$ S.E., $n=11)$ of 16 compounds from control and induced corn plants, $2 \mathrm{~h}$ into the scotophase. Induced plants (red bars) were fed upon by a single second instar fall armyworm larvae for $48 \mathrm{~h}$, control plants received no feeding (blue bars). ns $p>0.05,{ }^{*} \leq 0.05,{ }^{* *} \leq 0.01$. (1) (E)-2-Hexanal, (2) $\beta$-Myrcene, (3) (Z)-3-Hexan-1-ol, (4) (Z)-3-Hexenyl Acetate, (5) (Z)- $\beta$-Ocimene, (6) Linalool, (7) (E)-4,8-Dimethyl-1,3,7-Nonatriene, (8) Phenethyl Acetate, (9) Indole, (10) $\beta$-Caryophyllene, (11) $\beta$-Bergamotene, (12) (E)- $\beta$-Farnese, (13) $\alpha$-Humulene, (14) $\alpha$-Farnesene, (15) (E)-Nerolidol, (16) (3E,7E)-4,8,12-Trimethyl-1,3,7,11-Tridecatetraene.

\section{Discussion}

The significantly reduced egg mass numbers in the two-choice oviposition experiments indicates that conspecific feeding plays a dramatic role in fall armyworm oviposition preferences (Table 1). The published literature on damage-avoiding oviposition in female fall armyworms is limited, with four studies reporting significantly reduced oviposition on damaged corn plants compared with undamaged $[22,23,25,26]$ and one reporting no differences [27]. Larval feeding on induced corn tissue resulted in significantly decreased head capsule widths compared to larvae that were fed control corn tissue (Table 1). The live and dry weight data were both fairly variable, and a larger sample size may have resulted in statistical significance. The availability of larval feeding data is similarly limited; however, Acevedo et al. [28] recently reported that fall armyworm larvae that fed on corn plants with previous feeding damage gained less weight than larvae that fed on undamaged control plants [28]. Despite the dearth of current publications, the majority of the data that are present in published studies indicate that the effects of conspecific feeding in fall armyworm populations is a subject matter that warrants further examination for the identification of alternative management tools for this damaging pest.

Larval feeding in the targeted metabolomics experiment promoted a significant increase in the total concentrations of the targeted metabolites (Figure 1). This is reflected in the data for individual metabolites, which exhibited increased concentrations in response to all larval feeding with the exception of salicylic acid and cis-jasmonic acid, which showed no discernable changes in concentration; and trans-jasmonic acid, which did exhibit increased concentrations compared to control values, but not significantly so (Figure 2). This relative inactivity of these known defensive pathways suggests the 
possibility that fall armyworm feeding suppresses corn plant production of salicylic and jasmonic acids [29]. It is also interesting to note that the treatment with both prefeeding and feeding combined generally elicited lesser concentrations of the individual metabolites compared to the prefeeding only and feeding only treatments (Figure 2). This difference lacked significance in all of the targeted metabolites except for oleic acid and tetracosanoic acid, which were present in significantly lower concentrations in the combined treatment compared to the prefeeding only treatment but not the feeding only treatment (Figure 2). This generalized response to feeding exhibited by the corn plants does bear the potential to affect the fitness of active feeders, as evidenced by the results of the feeding trials. Linoleic acid has direct toxic effects on fall armyworm larvae [30,31] and it and its derivatives have been reported to cause fitness reductions in other Spodoptera [32-34]. TCAs consist of a series of organic acids that each possess three carboxylic acid groups and are most notable for their involvement in the citric acid cycle (sometimes referred to as the tricarboxylic acid cycle) of cellular respiration [35]. They also serve as "priming compounds" that induce the production of defensive compounds to combat stressors in plants [36,37].

The effects of corn plant defensive compounds on subsequent, conspecific feeders will be dependent on their persistence in the plant tissues. The lack of significant differences in the metabolomics profiles of the pre-feeding only and post-feeding only treatment groups in the targeted metabolomics analyses indicates that they may persist for at least $48 \mathrm{~h}$. This suggests a lag time between the initial induction of plant defenses due to fall armyworm feeding and the actual establishment of said chemical defenses. Ray et al. [29] determined that fall armyworm frass contains chitinases that suppress plant herbivore defenses and activate pathogen defenses, subsequently increasing larval performance. These chitinases may afford early instar larvae a certain "grace period" to feed and develop to resist plant defenses more effectively. It is also interesting to note that the lack of significant differences in the hatch rates of the egg masses collected in the oviposition trials indicates that these induced plant defenses do not affect the species' eggs to any significant degree. A follow up study determined that the same chitinases simulated the release increased levels of several HIPV's including $(E)-\beta$-farnesene (the aphid alarm pheromone [38]), $\alpha$-bergamotene, indole, linalool, acetic acid phenyl ester, and oximene, reducing aphid preferences for feeding or chemically induced corn plants when compared to undamaged plants [39].

VOC analyses detected significantly increased concentrations of $(E)$-2-hexanal, (Z)-3hexan-1-ol, (Z)-3-hexenyl acetate, (Z)- $\beta$-ocimene, linalool, (E)-4,8-dimethyl-1,3,7-nonatriene $(\mathrm{DMNT}),(E)$ - $\beta$-farnese, (E)-nerolidol, and (3E,7E)-4,8,12-trimethyl-1,3,7,11-tridecatetraene (TMTT) in corn plants induced by larval feeding compared to undamaged control plants (Figure 3). These results are partly consistent with Pinto-Zevallos et al. [40], who conducted similar VOC collections and identified significant differences in the concentrations of thirteen compounds. Pinto-Zevallos et al. [40] and this study both report significant differences in the concentrations ( $Z$ )-3-hexenyl acetate, $(Z)$ - $\beta$-ocimene, linalool, DMNT, (E)- $\beta$-farnese, and TMTT, though there are several differences in the overall VOC profiles and concentrations detected. The differences between the results of this study and PintosZevallos et al. [40] may be due to the use of different corn cultivars, as VOC profiles may vary across corn varieties [41].

The effects of (Z)- $\beta$-ocimene and Linalool on a variety of insect herbivores are well described, including oviposition deterrent, antifeedant, and parasitoid host location effects, in addition to the triggering of additional defense pathways [42-50]. DMNT, (E)- $\beta$-farnese, $(E)$ nerolidol, and TMTT, have also been reported as exerting oviposition deterrent effects across several insect species, including some Lepidoptera, among other possible effects [51-54].

(E)-2-hexanal, (Z)-3-hexan-1-ol, and (Z)-3-hexenyl acetate (Figure 3) are "green leaf volatiles" (GLVs), members of a group of compounds comprised of six-carbon alcohols, aldehydes, and esters that are commonly released due to mechanical damage and are perceivable by humans $[55,56]$. GLVs are often considered as having indirect effects on plant defenses by serving as chemical messengers or priming other plant defenses [57]. 
However, there is evidence for GLVs serving as direct oviposition deterrents in some insect species $[43,58,59]$. Therefore, the inclusion of GLVs when considering VOC profiles is still worthwhile.

Pinto-Zevallos et al. [40] also conducted electroantennaegrams on their identified VOCs, in which (Z)-3-hexenyl acetate, linalool, DMNT, $(E)$ - $\beta$-farnese, $(E)$-nerolidol, and TMTT all elicited antennal responses from the fall armyworm. This combined with the compound identification in this study and possible oviposition deterrent effects mark each as prime candidates for examination in IPM and IRM contexts.

A complicating, and often overlooked, aspect of fall armyworm biology in IPM and IRM is the existence of two host strains of the species, the "corn" and "rice" strains [60,61]. The strains are often differentiated from one another through their host preferences [62], though they are not absolute [62-65]. Several studies have identified differential tolerances in the fall armyworm host strains to several chemical insecticides $[18,62,66]$ and Bt toxins $[25,62,67-69]$. This is upheld by genetic data that depicts significant genetic variation between the corn and rice strains in nuclear and mitochondrial genes affecting detoxification, digestion, and chemoreception [70]. There is a report that larval feeding from the rice strain fall armyworm may induce greater concentrations of defensive compounds than corn strain larval feeding [71]. Therefore, follow up studies should include data on corn and rice strain fall armyworms (as well as corn-rice hybrids $[25,67]$ ) to further elucidate plant differential responses to host strain feeding.

\section{Materials and Methods}

\subsection{Study Insects and Colony Rearing}

Eggs from a corn strain fall armyworm population were obtained from the USDAARS station in Gainesville, FL, USA and used to establish a laboratory population. The population originated from Benzon Research Inc. in Carlisle, PA, USA and its corn strain identity was determined by USDA-ARS using the methods of Nagoshi et al. [72]. Four separate colonies of the population were maintained in the laboratory. The development of each colony was staggered by one week to ensure that each life stage was available for use in experiments at any given time. Colonies were all reared following the methods reported in Ingber et al. [67], modified from Perkins [73] and Vélez et al. [74], and all responded equally well to the rearing methods. All life stages were incubated in growth chambers (Model E-54U, Pervical Scientific, Perry, IA, USA) set to $27^{\circ} \mathrm{C}$ and a 16:8 L:D photoperiod. Relative humidity was maintained between $50 \%$ and $70 \%$ by placing large, water-filled containers at the bottom of each chamber. Egg masses were removed from population cages and incubated until larval emergence. Newly emerged neonates were transferred using a soft-tipped paint brush into 32-cell trays (Frontier Agricultural Sciences, Newark, DE, USA) prepared with $5 \mathrm{~mL}$ of general-purpose Lepidoptera diet (F9772, Frontier Agricultural Sciences, Newark, DE, USA) in each cell. Trays with larvae were sealed using lids with a thermal adhesive (Frontier Agricultural Sciences, Newark, DE, USA) and incubated until pupation.

Sealed trays were opened to obtain larvae for use in experiments and then resealed. Pupae were removed and placed atop cotton pads (Richmond Dental, Richmond, NC, USA) wet with deionized water in $100 \mathrm{~mm}$ petri dishes (Thermo Fisher Scientific Inc., Waltham, MA, USA) that were then placed in $20.3 \times 20.3 \times 20.3 \mathrm{~cm}, 6 \mathrm{~mm}$ wire mesh hermit crab cages (Florida Marine Research, Sarasota, FL, USA). The cages were fit with covers constructed of $1 \mathrm{~mm}$ wire mesh to prevent adult escape, as the $6 \mathrm{~mm}$ mesh of the cages themselves was not sufficient to contain smaller moths. A liquid adult diet comprised of flat beer, ascorbic acid, propionic acid, aureomycin, and a vitamin mixture (Vanderzant vitamin mix, Frontier Agricultural Sciences, Newark, DE, USA) $[67,73,74]$ was placed in each cage in a $50 \mathrm{~mL}$ Erlenmeyer flask (Thermo Fisher Scientific Inc., Waltham, MA, USA) fitted with a braided cotton wick (Richmond Dental, Richmond, NC, USA) after adult emergence was detected. Sheets of waxed paper (Reynolds Consumer Products, Lake 
Forest, IL, USA) were placed in between the cage wall and outer mesh cover to serve as an oviposition substrate and were replaced every three days.

\subsection{Plants}

Non-Bt field corn plants (35F38, Source: N3RUS11040-P7, Size: PDF, R3 Batch: 1063498U, Origin: Indiana; Corteva Agriscience, Wilmington, DE, USA) were grown in $15.24 \mathrm{~cm}$ diameter containers (TEKU Azalea Style, Poppelmann Plastics USA LLC, Claremont, NC, USA) filled with SunGro Metro-Mix 855 growing mix (SunGro Horticulture, Vancouver, BC, Canada), with one seedling per container, in a greenhouse. This cultivar was selected due to its widespread use in commercial field corn operations. Daily greenhouse conditions ranged between $28{ }^{\circ} \mathrm{C}$ and $35^{\circ} \mathrm{C}$ and $40 \%$ and $70 \%$ relative humidity depending on the outside weather conditions. Corn seeds were soaked in a $10 \%$ bleach solution for one hour in order to remove any seed treatments. Bleached seeds were rinsed in tap water then left out to dry for at least $24 \mathrm{~h}$ prior to planting. Corn plants were grown to approximately the V4-V5 growth stage prior to use in experiments. Cohorts of 20 plants were planted each week to ensure that corn plants of the correct growth stage are always available for use in experiments.

\subsection{Two-Choice Oviposition Experiment}

Fourth instar fall armyworm larvae were placed in the whorl of V6-8 corn plants, one per plant, in the greenhouse. These plants were referred to as "induced" plants, and larvae were allowed to feed for a $48 \mathrm{~h}$ period to ensure sufficient feeding damage. Plants with larvae were placed in $60 \mathrm{~cm} \times 60 \mathrm{~cm} \times 75 \mathrm{~cm}$ insect rearing tents (Bugdorm, MegaView Science Co. Ltd., Taichung, Taiwan) to prevent larval escape. After the $48 \mathrm{~h}$ period elapsed, one induced plant and one undamaged control plant were placed on opposite sides of $200 \times 180 \times 150 \mathrm{~cm}$ pop up mosquito nets (Yoosion Moustiquaire Bed Zipper, ShenZhen Kafan Technology Co. Ltd., ShenZhen, China). A single, gravid, female fall armyworm was released into the mosquito net and left for $96 \mathrm{~h}$ to oviposit. Females were removed from rearing cages after $72 \mathrm{~h}$ of mass-mating post initial adult emergence. After the oviposition period had elapsed, the plants were removed from the mosquito net and the remaining larval and adult fall armyworm were disposed of. The number of egg masses on each plant was recorded. Egg masses could be of any number of eggs and were considered discrete from one another as long as they were at least $1 \mathrm{~cm}$ apart. Twelve cohorts consisting of four mosquito nets each were conducted for a total of 48 repetitions of the two-choice oviposition experiment. Collected egg masses were separated into individual $44.4 \mathrm{~mL}$ plastic cups (Solo T125-0090 plastic soufflé portion cups, Solo Cup Company, Hampstead, $\mathrm{MD}, \mathrm{USA})$, placed in a growth chamber, and monitored for larval emergence. After larval emergence, the number of hatched eggs and total number of eggs were counted using a Wild M5A stereomicroscope (Wild-Heerbrugg, Heerbrugg, Switzerland) to determine the hatch rates of the deposited egg masses.

\subsection{Feeding Trials}

Induced plants were prepared in the same manner as in the two-choice oviposition experiment. After the $48 \mathrm{~h}$ feeding period, the fourth instar larvae were removed from the induced plants. After removal of the original larvae, fresh second instar larvae were placed in the whorls of each induced plant and control plants that received no prior feeding damage. Fall armyworm larvae typically begin feeding on their initial host plant after neonate emergence. Second instar larvae were used to simulate this while simultaneously avoiding the increased mortality rates exhibited by first instars. Plants with larvae were placed in individual $60 \mathrm{~cm} \times 60 \mathrm{~cm} \times 75 \mathrm{~cm}$ insect rearing tents (Bugdorm, MegaView Science Co. Ltd., Taichung, Taiwan), where the second instar larvae were left to feed for a $96 \mathrm{~h}$ period. The second instar larvae were recovered after the feeding period had elapsed. Twelve cohorts of two induced and two control plants each were conducted for 24 repetitions of each plant type. Thirteen larvae were recovered from induced plants and 
14 from control plants. The head capsule widths of recovered larvae were measured using a using a Wild M5A stereomicroscope with a stock 20×, 5:100 measuring eyepiece (Wild Heerbrugg, Heerbrugg, Switzerland). Live weights were measured using an electronic balance (Mettler Toledo AL54, Mettler Toledo LLC, Bristol, PA, USA). After obtaining the live weight measurements, larvae were desiccated using a drying oven (Gravity Oven 180 L, Fisher Scientific Company, LLC, Waltham, MA, USA), then re-weighed to measure their dry weights.

\subsection{Targeted Metabolomic Analyses}

Induced plants were prepared in the same manner as in the previous two experiments, serving as a "prefeeding" phase for this experiment. After the initial induction period had elapsed, fresh second instar larvae were placed into the whorls of a subset of induced and control plants for a second induction period to serve as a "feeding" phase. Therefore, the treatments for this experiment are no feeding, feeding only, prefeeding only, and prefeeding and feeding together. All plants were left undisturbed for a $6 \mathrm{~h}$ period after the initiation of the second induction phase after which time $3 \mathrm{~cm}$ leaf sections were removed from green, complete leaves from the whorls and outer leaves of each plant and immediately submerged into liquid nitrogen. For quantification of maize metabolites described in this work, samples were solvent extracted, methylated, collected on a polymeric adsorbent using vapor-phase extraction (VPE), and analyzed using GC/isobutane CI-MS as previously described in Schmelz et al. [75]. Metabolite quantification was based on d6-SA (Sigma-Aldrich, St. Louis, MO, USA), d5-JA (C/D/N Isotopes Inc, Pointe-Claire, QC, Canada), or U13C-18:3 (Cambridge Isotope Laboratories Inc., Tewksbury, MA, USA), as internal standards.

\subsection{Volatile Organic Compound (VOC) Collection and Analysis}

V6 maize plants were placed into glass chambers $(20 \mathrm{~cm}$ diameter, $80 \mathrm{~cm}$ height $)$ adapted from Turlings et al. [76]. The pots containing the plants were wrapped into aluminum foil to reduce contamination with the volatile organic compound from the soil/potting mix. The corn plants were induced using the two first instar fall armyworms placed into the whorl. After $24 \mathrm{~h}$, trapping filters (30 mg of HayeSep Q, $4 \mathrm{~mm}$ diameter, $8.8 \mathrm{~cm}$ long; Volatile Assay Systems, NY, USA) conditioned with $3 \mathrm{~mL}$ of dichloromethane (GC-grade; Sigma-Aldrich, MO, USA) were inserted into horizontally connected glass ports and secured with screw cap fittings. The filters were then connected to an air flowmeter and vacuum pump. A Teflon tube (Volatile Assay Systems, Rensselaer, NY, USA) was inserted in a second glass port located at the bottom of the VOC collection chamber $(20 \mathrm{~cm}$ high, ca. $2 \mathrm{~cm}$ above the pot). Purified air entered the system $(1.2 \mathrm{~L} / \mathrm{min})$ through the Teflon tube and was pulled out of the glass vessel at a rate of $0.6 \mathrm{~L} / \mathrm{min}$, through the trapping filters. Odor collection started $2 \mathrm{~h}$ into the scotophase and lasted for $3 \mathrm{~h}$. After volatile trapping was completed, the filters were eluted with $200 \mu \mathrm{L}$ of dichloromethane (GC-grade; Sigma-Aldrich, St Louis, MO, USA) following D'Alessandro et al. [77]. A control consisted of corn plants of the same growth stage, but without induction. A total of 11 samples were collected for each treatment (Induced and Control), and two internal standards were added ( $n$-octane and nonyl acetate, $200 \mathrm{ng}$ each in $10 \mu \mathrm{L}$ dichloromethane; Sigma-Aldrich, St Louis, MO, USA). VOC samples were stored in a freezer at $-80^{\circ} \mathrm{C}$ prior to their analysis.

Volatiles were analyzed with an Agilent 6890 gas chromatographer (Agilent Technologies Inc., Santa Clara, CA, USA) equipped with a mass spectrometer (Agilent 5973 Network Mass Selective Detector, transfer line $230^{\circ} \mathrm{C}$, source $230^{\circ} \mathrm{C}$, ionization potential $70 \mathrm{eV}$; Agilent Technologies Inc., Santa Clara, CA, USA). Aliquots of $3 \mu \mathrm{L}$ of each sample were injected using the pulsed splitless mode into an apolar capillary column (HP-5MS, $30 \mathrm{~m}, 0.25 \mathrm{~mm}$ ID, $0.25 \mu \mathrm{m}$ film thickness, Agilent Technologies Inc., Santa Clara, CA, USA). Helium was used as the carrier gas at a constant pressure of $1.6 \mathrm{psi}, 1.2 \mathrm{~mL} / \mathrm{min}$. The column temperature was maintained at $40^{\circ} \mathrm{C}$ for $2 \mathrm{~min}$ after injection and then gradually increased to $100^{\circ} \mathrm{C}$ at a rate of $9{ }^{\circ} \mathrm{C} / \mathrm{min}$, then again to $200^{\circ} \mathrm{C}$ at $6{ }^{\circ} \mathrm{C} / \mathrm{min}$. Volatiles were putatively identified by comparison of their mass spectra with those of the NIST 08 library. 
The relative concentrations of the compounds were estimated by comparison to those of the internal standards.

\subsection{Data Analyses}

Data comparing the control and induced groups in both the two-choice oviposition experiments and feeding trials were compared in SAS 9.4 (SAS Institute Inc., Cary, NC, USA). Data pertaining to the targeted metabolomic and HIPVs profiles of control and induced plants were compared in R 4.0.5.

The mean number of egg masses deposited on control and induced plants were compared using a generalized linear model with a Quasi-Poisson distribution (PROC GLIMMEX) as the number of egg masses deposited on each plant within each trial were not independent from one another [78]. The mean proportion of hatched eggs from masses collected from control and induced plants were compared with a $t$-test (PROC TTEST). T-tests were also employed to compare the mean live and dry weights, and head capsule widths of surviving larvae in the feeding trials.

A linear discriminant analysis (LDA) was conducted to determine the effects of the four treatments (no feeding, feeding only, prefeeding only, and feeding and prefeeding together) on the targeted corn plant metabolites. The assumption of homogeneity was met in permutations (permutation test following Kergunteuil et al. [79], permutation $=999$, $\mathrm{F}=0.0 .99, p=0.431)$. The differences in the distribution of the metabolic profiles along LD1 were tested using a pairwise Wilcoxon signed-rank test with a Benjamini-Hochberg adjustment to the level of significance. The concentrations of individual metabolites between treatment groups were compared using one-way ANOVA followed by TukeyKramer adjusted pairwise comparisons if the overall model was significant.

Data comparing the collected volatile profiles of induced and control plants as well as the total average VOC concentrations of each plant type were analyzed using two-sample $t$-tests.

\section{Conclusions}

The present study partially elucidates why FAW gravid females avoid plants damaged by conspecifics due to the plants emitting possibly repellent VOCs and affecting the development of their progeny. The outcomes of this research may offer several HIPVs that could be used as foliar deterrents and eventually be incorporated into new transgenic plant varieties [80]. Further inquiries could include host strain specific data, foliar treatments using identified metabolites, additional feeding trial time points (e.g., $24 \mathrm{~h}$ and $72 \mathrm{~h}$ ), and leaf damage values to correlate with larval growth factors. The timely production of novel management techniques could be a large boon for their agricultural practices and industries by providing a safe and effective means of pest management.

Author Contributions: Conceptualization, D.A.I. and I.H.; methodology, D.A.I., I.H. and S.A.C.; software, D.A.I., I.H. and S.A.C.; validation, D.A.I. and I.H.; formal analysis, D.A.I., I.H. and S.A.C.; investigation, D.A.I., I.H., S.A.C. and H.T.A.; resources, I.H., S.A.C. and H.T.A.; data curation, D.A.I., I.H. and S.A.C.; writing—original draft preparation, D.A.I.; writing—review and editing, D.A.I., I.H., S.A.C. and H.T.A.; visualization, D.A.I. and I.H.; supervision, I.H.; project administration, I.H.; funding acquisition, I.H. All authors have read and agreed to the published version of the manuscript.

Funding: This research was supported by the University of Delaware, Corteva Agriscience, and by the USDA National Institute of Food and Agriculture Grant no. 2015-31100-06010 authorized under the Hatch Act.

Institutional Review Board Statement: Not applicable.

Informed Consent Statement: Not applicable.

Data Availability Statement: Data supporting the reported results are in the possession of D.A.I. and I.H. and are available upon request. Data are also publically available through MDPI. 
Acknowledgments: Robert Meagher and Amy Rowley of the USDA-ARS station in Gainesville, FL provided fall armyworm eggs for laboratory populations. Ana Vélez of the University of NebraskaLincoln Department of Entomology, Bruce Lang of Custom Bio Products, and Michael Vella of Frontier Agricultural Sciences provided assistance in optimizing the fall armyworm colony rearing methodologies utilized.

Conflicts of Interest: The authors declare no conflict of interest.

\section{References}

1. Luginbill, P. The fall armyworm. USDA Tech. Bull. 1928, 34, 1-93.

2. Sparks, A.N. A Review of the Biology of the Fall Armyworm. Fla. Entomol. 1979, 62, 82. [CrossRef]

3. Pashley, D.P. Current Status of Fall Armyworm Host Strains. Fla. Entomol. 1988, 71, 227. [CrossRef]

4. Young, J.R. Fall Armyworm: Control with Insecticides. Fla. Entomol. 1979, 62, 130. [CrossRef]

5. Johnson, S.J. Migration and the life history strategy of the fall armyworm, Spodoptera frugiperda in the western hemisphere. Int. J. Trop. Insect Sci. 1987, 8, 543-549. [CrossRef]

6. Cruz, L.; Turpin, F.T. Yield impact of larval infestations of the fall armyworm (Lepidoptera: Noctuidae) to midwhorl growth stages of corn. J. Econ. Entomol. 1983, 76, 1052-1054. [CrossRef]

7. Barros, E.M.; Torres, J.B.; Bueno, J.F. Oviposition, development, and reproduction of Spodoptera frugiperda (J. E. Smith) (Lepidoptera: Noctuidae) fed on different hosts of economic importance. Neotrop. Entomol. 2010, 39, 996-1001. [CrossRef] [PubMed]

8. Murúa, M.G.; Nagoshi, R.N.; Dos Santos, D.A.; Hay-Roe, M.M.; Meagher, R.K.; Vilardi, J.C. Demonstration using field col-lections that Argentina fall armyworm populations exhibit strain-specific host plant preferences. J. Econ. Entomol. 2015, 108, 2305-2315. [CrossRef]

9. Georgen, G.; Kumar, P.L.; Sankungh, S.B.; Togola, A.; Tamò, M. First report of outbreaks of the fall armyworm Spodoptera frugiperda (J. E. Smith) (Lepidoptera, Noctuidae), a new alien invasive pest in west and central Africa. PLoS ONE 2016, 11, e0165632.

10. Stokstad, E. New crop pest takes Africa at lightning speed. Science 2017, 356, 473-474. [CrossRef] [PubMed]

11. Sharanabasappa; Kalleshwaraswamy, C.M.; Asokan, R.; Swamy, H.W.; Maruthi, M.S.; Pavithra, H.B.; Hegde, K.; Navi, S.; Prabhu, S.T.; Goergen, G. First report of the fall armyworm, Spodoptera frugiperda (J E Smith) (Lepidoptera: Noctuidae), an alien invasive pest on maize in India. Pest Manag. Hort. Ecosys. 2018, 24, 23-29.

12. Kalleshwaraswamy, C.M.; Asokan, R.; Mahadevaswamy, H.M.; Sharanabasappa. First record of invasive fall armyworm, Spodoptera frugiperda (J. E. Smith) (Lepidoptera: Noctuidae) on rice (Oryza sativa) from India. J. Entomol. Zool. Stud. 2019, 7, 332-337.

13. Guo, J.; Zhao, J.; He, K.; Zhang, F.; Wang, Z. Potential invasion of the crop-devastating insect pest fall armyworm Spodoptera frugiperda to China. Plant Prot. 2018, 44, 1-10.

14. Sun, X.-X.; Hu, C.-X.; Jia, H.-R.; Wu, Q.-L.; Shen, X.-J.; Zhao, S.-Y.; Jiang, Y.-Y.; Wu, K.-M. Case study on the first immigration of fall armyworm, Spodoptera frugiperda invading into China. J. Integr. Agric. 2021, 20, 664-672. [CrossRef]

15. Jing, D.; Guo, J.; Jiang, Y.; Zhao, J.; Sethi, A.; He, K.; Wang, S. Initial detections and spread of invasive Spodoptera frugiperda in Chin and comparisons with other noctuid larvae in cornfield using molecular techniques. Insect Sci. 2020, 27, 780-790. [CrossRef]

16. ADAWE (Australian Department of Agriculture, Water, and the Environment). Fall Armyworm Detected in Torres Strait. 2020. Available online: https:/ / www.awe.gov.au/news/media-releases/fall-armyworm-detected-torres-strait (accessed on 1 June 2021).

17. Yu, S. Insecticide resistance in the fall armyworm, Spodoptera frugiperda (J. E. Smith). Pestic. Biochem. Physiol. 1991, 39, 84-91. [CrossRef]

18. Ríos-Díez, J.D.; Saldamando-Benjumea, C.I. Susceptibility of Spodoptera frugiperda (Lepidoptera: Noctuidae) strains from central Colombia to two insecticides, methomyl and lambda-cyhalothrin: A study of the genetic basis of resistance. J. Econ. Entomol. 2011, 104, 1698-1705. [CrossRef]

19. Carvalho, R.A.; Omoto, C.; Field, L.M.; Williamson, M.S.; Bass, C. Investigating the molecular mechanisms of organo-phosphate and pyrethroid resistance in the fall armyworm, Spodoptera frugiperda. PLoS ONE 2013, 8, e62268. [CrossRef] [PubMed]

20. Zhu, Y.; Blanco, C.; Portilla, M.; Adamczyk, J.J.; Lutrell, R.; Huang, F. Evidence of multiple/cross resistance to Bt and organophosphate insecticides in Puerto Rico populations of the fall armyworm, Spodoptera frugiperda. Pestic. Biochem. Physiol. 2014, 122, 15-21. [CrossRef]

21. Storer, N.P.; Babcock, J.M.; Schlenz, M.; Meade, T.; Thompson, G.T.; Bing, J.W.; Huckaba, R.M. Discovery and characteri-zation of field resistance to Bt maize: Spodoptera frugiperda (Lepidoptera: Noctuidae) in Puerto Rico. J. Econ. Entomol. 2010, 103, 1031-1038. [CrossRef]

22. Signoretti, A.G.C.; Peñaflor, M.F.G.V.; Bento, J.M.S. Fall Armyworm, Spodoptera frugiperda (J.E. Smith) (Lepidoptera: Noctuidae), Female Moths Respond to Herbivore-Induced Corn Volatiles. Neotropical Entomol. 2012, 41, 22-26. [CrossRef] [PubMed]

23. Téllez-Rodríguez, P.; Raymond, B.; Morán-Bertot, I.; Rodríguez-Cabrera, L.; Wright, D.J.; Borroto, C.G.; Ayra-Pardo, C. Strong oviposition preference for Bt over non-Bt maize in Spodoptera frugiperda and its implications for the evolution of resistance. BMC Biol. 2014, 12, 48. [CrossRef] [PubMed]

24. Hardke, J.T.; Leonard, B.R.; Huang, F.; Jackson, R. Damage and survivorship of fall armyworm (Lepidoptera: Noctuidae) on transgenic field corn expressing Bacillus thuringiensis Cry proteins. Crop. Prot. 2011, 30, 168-172. [CrossRef] 
25. A Ingber, D.; McDonald, J.H.; E Mason, C.; Flexner, L. Oviposition preferences, Bt susceptibilities, and tissue feeding of fall armyworm (Lepidoptera: Noctuidae) host strains. Pest Manag. Sci. 2021, 77, 4091-4099. [CrossRef] [PubMed]

26. He, L.-M.; Zhao, S.Y.; Gao, X.-W.; Wu, K.-M. Ovipositional responses of Spodoptera frugiperda on host plants provide a basis for using Bt-transgenic maize as a trap crop in China. J. Integr. Agric. 2021, 20, 804-814. [CrossRef]

27. Gonçalves, J.; Rodrigues, J.V.C.; Amaya, O.F.S.; Paula-Moraes, S.V.; Pereira, E.J.G. The oviposition behavior of fall armyworm moths is unlikely to compromise the refuge strategy in genetically modified Bt crops. J. Pest. Sci. 2020, 93, 965-977. [CrossRef]

28. Acevedo, F.E.; Peiffer, M.; Ray, S.; Tan, C.-W.; Felton, G.W. Silicon-mediated enhancement of herbivore resistance in agri-cultural crops. Front. Plant Sci. 2021, 12, 116-133. [CrossRef]

29. Ray, S.; Alves, P.C.; Ahmad, I.; Gaffoor, I.; Acevedo, F.E.; Peiffer, M.; Jin, S.; Han, Y.; Shakeel, S.; Felton, G.W.; et al. Turnabout Is Fair Play: Herbivory-Induced Plant Chitinases Excreted in Fall Armyworm Frass Suppress Herbivore Defenses in Maize. Plant Physiol. 2016, 171, 694-706. [CrossRef]

30. Figueroa, R.; Camino, M.; Pérez-Amador, M.C.; Muñoz, V.; Bratoeff, E.; Labastida, C. Fatty acid composition and toxic actiity of the acetonic extract of Carica papaya L. (Caricaceae) seeds. Phyton 2002, 51, 97-99.

31. Ramos-López, M.A.; González-Chávez, M.M.; Cárdenas-Ortega, N.C.; Zavala-Sánchez, M.A.; Pérez, S. Activity of the main fatty acid components of the hexane leaf extract of Ricinus communis against Spodoptera frugiperda. Afr. J. Biotechnol. 2012, 11, 4274-4278. [CrossRef]

32. Barakat, A.A.; El-Mahy, S.A.; Moustafa, O.K.; Mansour, A.F.; El-Hadek, M.K. Biological effect of Cassia fistula (L.) seeds against the cotton leafworm Spodoptera littoralis (Boisd.) With special reference to chemical constituents. Bull. Ent. Soc. Egypt. Econ. Ser. 2004, 30, 1-14.

33. Heba, Y.; El Akwah, S.F.; El Sayed, Y.A. Insecticidal activitiy of linoleic acid against Spodoptera littoralis (Boisd). Egypt J. Agric. 2013, 91, 573-579.

34. Vatanparast, M.; Ahmed, S.; Lee, D.-H.; Hwang, S.H.; Hammock, B.; Kim, Y. EpOME's act as immune suppressors in a lepidopteran insect, Spodoptera exigua. Sci. Rep. 2020, 10, 20183. [CrossRef] [PubMed]

35. Urry, L.A.; Michael, C.L.; Wasserman, S.A.; Alexander, S.; Minorsky, P.V.; Orr, R.B.; Campbell, N.A. Cellular Respiration and Fermentation. Campbell Biology, 12th ed.; Pearson: New York, NY, USA, 2021.

36. Pastor, V.; Balmer, A.; Gamir, J.; Flors, V.; Mauch-Mani, B. Preparing to fight back: Generation and storage of priming compounds. Front. Plant Sci. 2014, 5, 295. [CrossRef]

37. Balmer, A.; Pastor, V.; Glauser, G.; Mauch-Mani, B. Tricarboxylates Induce Defense Priming Against Bacteria in Arabidopsis thaliana. Front. Plant Sci. 2018, 9. [CrossRef] [PubMed]

38. Gibson, R.W.; Pickett, J.A. Wild potato repels aphids by release of aphid alarm pheromone. Nature 1983, 302, 608-609. [CrossRef]

39. Ray, S.; Helms, A.M.; Matulis, N.L.; Davidson-Lowe, E.; Grisales, W.; Ali, J.G. Asymmetry in Herbivore Effector Responses: Caterpillar Frass Effectors Reduce Performance of a Subsequent Herbivore. J. Chem. Ecol. 2019, 46, 76-83. [CrossRef]

40. Pinto-Zevallos, D.M.; Strapasson, P.; Zarbin, P.H.G. Herbivore-induced volatile organic compounds emitted by maize: Electrophysiological responses in Spodoptera frugiperda females. Phytochem. Lett. 2016, 16, 70-74. [CrossRef]

41. Gouinguené, S.; Degen, T.; Turlings, T.C.J. Variability in herbivore-induced odour emissions among maize cultivars and their wild ancestors (teosinte). Chemoecology 2001, 11, 9-16. [CrossRef]

42. De Moraes, C.M.; Mescher, M.C.; Tumlinson, J.H. Caterpillar-induced nocturnal plant volatiles repel conspecific females. Nature 2001, 410, 577-580. [CrossRef]

43. Kessler, A.; Baldwin, I.T. Defensive function of herbivore-induced plant volatile emissions in nature. Science 2001, 291, 2141-2143. [CrossRef] [PubMed]

44. Aharoni, A.; Giri, A.P.; Deuerlein, S.; Griepink, F.; de Kogel, W.J.; Verstappen, F.W.A.; Verhoeven, H.A.; Jongsma, M.; Schwab, W.; Bouwmeester, H. Terpenoid Metabolism in Wild-Type and Transgenic Arabidopsis Plants. Plant Cell 2003, 15, $2866-2884$. [CrossRef]

45. Zhang, M.-X.; Ling, B.; Chen, S.; Liang, G.-W.; Pang, X.-F. Repellent and oviposition deterrent activities of the essential oil from mikania micrantha and its compounds on plutella xylostella. Insect Sci. 2004, 11, 37-45. [CrossRef]

46. Kostić, M.; Popović, Z.; Brkić, D.; Milanović, S.; Sivčev, I.; Stanković, S. Larvicidal and antifeedant activity of some plant-derived compounds to Lymantria dispar L. (Lepidoptera: Limantriidae). Bioresour. Technol. 2008, 99, 7897-7901. [CrossRef] [PubMed]

47. McCallum, E.J.; Cunningham, J.P.; Lucker, J.; Zalucki, M.P.; De Voss, J.J.; Botella, J.R. Increased plant volatile production affects oviposition, but not larval development in the moth Helicopverpa armigera. J. Exp. Biol. 2011, 214, 3672-3677. [CrossRef] [PubMed]

48. Yang, T.; Stoopen, G.; Thoen, M.; Wiegers, G.; Jongsma, M.A. Chrysanthemum expressing a linalool synthase gene 'smells good', but 'tastes bad' to western flower thrips. Plant Biotechnol. J. 2013, 11, 875-882. [CrossRef] [PubMed]

49. Kang, Z.-W.; Liu, F.-H.; Zhang, Z.-F.; Tian, H.-G.; Liu, T.-X. Volatile $\beta$-Ocimene Can Regulate Developmental Performance of Peach Aphid Myzus persicae Through Activation of Defense Responses in Chinese Cabbage Brassica pekinensis. Front. Plant Sci. 2018, 9. [CrossRef] [PubMed]

50. Papanastasiou, S.A.; Ioannou, C.S.; Papadopoulos, N.T. Oviposition-deterrent effect of linalool—A compound of citrus es-sential oils-On female Mediterranean fruit flies, Ceratitis capitata (Diptera: Tephritidae). Pest Manag. Sci. 2020, 76, 3066-3077. [CrossRef] 
51. Binder, B.F.; Robbins, J.C. Effect of Terpenoids and Related Compounds on the Oviposition Behavior of the European Corn Borer, Ostrinia nubilalis(Lepidoptera: Pyralidae). J. Agric. Food Chem. 1997, 45, 980-984. [CrossRef]

52. Hatano, E.; Saveer, A.M.; Borrero-Echeverry, F.; Strauch, M.; Zakir, A.; Bengtsson, M.; Ignell, R.; Anderson, P.; Becher, P.G.; Witzgall, P.; et al. A herbivore-induced plant volatile interferes with host plant and mate location in moths through suppression of olfactory signalling pathways. BMC Biol. 2015, 13, 1-15. [CrossRef] [PubMed]

53. Li, F.; Dewer, Y.; Li, D.; Qu, C.; Luo, C. Functional and evolutionary characterization of chemosensory proteinCSP2 in the whitefly, Bemisia tabaci. Pest Manag. Sci. 2020, 77, 378-388. [CrossRef]

54. Markheiser, A.; Rid, M.; Biancu, S.; Gross, J.; Hoffmann, C. Tracking Short-Range Attraction and Oviposition of European Grapevine Moths Affected by Volatile Organic Compounds in a Four-Chamber Olfactometer. Insects 2020, 11, 45. [CrossRef]

55. Turlings, T.C.; Loughrin, J.; McCall, P.; Rose, U.S.; Lewis, W.J.; Tumlinson, J.H. How caterpillar-damaged plants protect themselves by attracting parasitic wasps. Proc. Natl. Acad. Sci. USA 1995, 92, 4169-4174. [CrossRef] [PubMed]

56. Turlings, T.C.J.; Lengwiler, U.B.; Bernasconi, M.L.; Wechsler, D. Timing of induced volatile emissions in maize seedlings. Planta 1998, 207, 146-152. [CrossRef]

57. Scala, A.; Allmann, S.; Mirabella, R.; Haring, M.A.; Schuurink, R.C. Green Leaf Volatiles: A Plant's Multifunctional Weapon against Herbivores and Pathogens. Int. J. Mol. Sci. 2013, 14, 17781-17811. [CrossRef] [PubMed]

58. Sánchez-Hernández, C.; López, M.G.; Délano-Frier, J.P. Reduced levels of volatile emissions in jasmoate-deficient spr2 mutants favour oviposition by insect herbivores. Plant Cell Environ. 2006, 26, 546-557. [CrossRef] [PubMed]

59. Allmann, S.; Späthe, A.; Bisch-Knaden, S.; Kallenbach, M.; Reinecke, A.; Sachse, S.; Baldwin, I.T.; Hansson, B.S. Feed-ing-induced rearrangement of green leaf volatiles reduces moth oviposition. eLife 2013, 2, e00421. [CrossRef] [PubMed]

60. Pashley, D.P.; Johnson, S.J.; Sparks, A.N. Genetic Population Structure of Migratory Moths: The Fall Armyworm (Lepidoptera: Noctuidae). Ann. Entomol. Soc. Am. 1985, 78, 756-762. [CrossRef]

61. Pashley, D. Host-associated genetic differentiation in fall armyworm (Lepidoptera: Noctuidae): A sibling species complex? Ann. Entomol. Soc. Am. 1986, 79, 898-904. [CrossRef]

62. Adamczyk, J.J.; Holloway, J.W.; Leonard, B.R.; Graves, J.B. Susceptibility of fall armyworm collected from different plant hosts to selected insecticides and transgenic Bt cotton. J. Cotton Sci. 1997, 1, 21-28.

63. Luttrell, R.G.; Mink, J.S. Damage to cotton fruiting structures by the fall armyworm Spodoptera frugiperda (Lepidoptera: Noctuidae). J. Cotton Sci. 1999, 3, 35-44.

64. Prowell, D.P.; McMichael, M.; Silvain, J.-F. Multilocus Genetic Analysis of Host Use, Introgression, and Speciation in Host Strains of Fall Armyworm (Lepidoptera: Noctuidae). Ann. Entomol. Soc. Am. 2004, 97, 1034-1044. [CrossRef]

65. Groot, A.T.; Marr, M.; Heckel, D.; SchÖfl, G. The roles and interactions of reproductive isolation mechanisms in fall armyworm (Lepidoptera: Noctuidae) host strains. Ecol. Entomol. 2010, 35, 105-118. [CrossRef]

66. Pashley, D.; Sparks, T.C.; Quisenberry, S.W.; Jamjanya, T.; Dowd, P.F. Two fall armyworm strains feed on corn, rice, and Bermuda grass. Louisiana Agric. 1987, 30, 8-9.

67. A Ingber, D.; E Mason, C.; Flexner, L. Cry1 Bt Susceptibilities of Fall Armyworm (Lepidoptera: Noctuidae) Host Strains. J. Econ. Entomol. 2017, 111, 361-368. [CrossRef] [PubMed]

68. Virla, E.G.; Álvarez, A.; Loto, F.; Pera, L.M.; Baigori, M.D. Fall Armyworm Strains (Lepidoptera: Noctuidae) in Argentina, Their Associate Host Plants and Response to Different Mortality Factors in Laboratory. Fla. Entomol. 2008, 91, 63-69. [CrossRef]

69. Ríos-Díez, J.D.; Siegfried, B.; Saldamando-Benjumea, C.I. Susceptibility of Spodoptera frugiperda (Lepidoptera: Noctuidae) Strains from Central Colombia to Cry1Ab and Cry1Ac Entotoxins ofBacillus thuringiensis. Southwest. Entomol. 2012, 37, $281-293$. [CrossRef]

70. Gouin, A.; Bretaudeau, A.; Nam, K.; Gimenez, S.; MarcAury, J.; Duvic, B.; Hilliou, F.; Durand, N.; Montagné, N.; Darboux, I.; et al Two genomes of highly polyphagous lepidopteran pests (Spodoptera frugiperda, Noctuidae) with different host-plant ranges. Sci. Repor. 2017, 7, 11816. [CrossRef] [PubMed]

71. Acevedo, F.E.; Peiffer, M.; Ray, S.; Meagher, R.; Luthe, D.S.; Felton, G.W. Intraspecific differences in plant defense induction by fall armyworm strains. New Phytol. 2018, 218, 310-321. [CrossRef]

72. Nagoshi, R.N.; Silvie, P.; Meagher, R.L. Comparison of haplotype frequencies differentiate fall armyworm (Lepidoptera: Noctuidae) corn-strain populations from Florida and Brazil. J. Econ. Entomol. 2007, 100, 654-961. [CrossRef]

73. Perkins, W.D. Laboratory Rearing of the Fall Armyworm. Fla. Entomol. 1979, 62, 87. [CrossRef]

74. Vélez, A.M.; Spencer, T.A.; Alves, A.P.; Moellenbeck, D.; Meagher, R.L.; Chirakkal, H.; Siegfried, B.D. Inheritance of Cry1F resistance, cross-resistance and frequency of resistant alleles in Spodoptera frugiperda (Lepidoptera: Noctuidae). Entomol. Res. 2013, 103, 700-713. [CrossRef] [PubMed]

75. Schmelz, E.A.; Engelberth, J.; Tumlinson, J.H.; Block, A.; Alborn, H.T. The use of vapor phase extraction in metabolic pro-filing of phytohormones and other metabolites. Plant J. 2004, 39, 790-808. [CrossRef] [PubMed]

76. Turlings, T.C.J.; Davison, A.C.; Tamò, C. A six-arm olfactometer permitting simultaneous observation of insect attraction and odour trapping. Physiol. Entomol. 2004, 29, 45-55. [CrossRef]

77. D'Alessandro, M.; Brunner, V.; von Mérey, G.; Turlings, T.C.J. Strong attraction of the parasitoid Cotesia marginiventris to-wards minor volatile compounds of maize. J. Chem. Ecol. 2009, 35, 999-1008. [CrossRef]

78. Ramsey, F.L.; Schafer, D.W. The Statistical Sleuth, 2nd ed.; Log-Linear Regression for Poisson Counts; Cengage Learning: Belmont, CA, USA, 2002. 
79. Kergunteuil, A.; Röder, G.; Rasmann, S. Environmental gradients and the evolution of tri-trophic interactions. Ecol. Lett. 2018, 22, 292-301. [CrossRef] [PubMed]

80. Degenhardt, J.; Hiltpold, I.; Köllner, T.G.; Frey, M.; Gierl, A.; Gershenzon, J.; Hibbard, B.E.; Ellersieck, M.R.; Turlings, T.C.J. Restoring a maize root signal that attracts insect-killing nematodes to control a major pest. Proc. Natl. Acad. Sci. USA 2009, 106, 13213-13218. [CrossRef] 